Tak więc stan permanentnej dokumentacji, w jakim od wielu lat uczestniczę, nie ma pustych przebiegów. Każda zaobserwowana chwila odkłada się gdzieś w pamięci i nie wiadomo kiedy i w jakiej formie z powrotem wypłynie. Wystarczy być tylko ciekawym i otwartym na świat[1].

Pierwsze projekty filmowe i pierwsze filmy powstają podczas studiów w moskiewskiej szkole filmowej WGIK. Studenci eksperymentalnego kursu Lwa Kulidżanowa zgłębiają przede wszystkim tajniki kina fabularnego i pracy z aktorem według metody Stanisławskiego. Studia w Moskwie to jednak nie tylko czas obcowania z kulturą i intensywnego rozwoju intelektualnego, ale również czas urabiania dusz, nieustannej indoktrynacji prowadzonej często bardzo wyrafinowanymi metodami. W konsekwencji w twórczości Drygasa na zawsze pozostanie opór wobec totalitaryzmu i humanistyczna wrażliwość.

Jako film dyplomowy Drygas realizuje fabularny Falstart (1981) opowieść o studencie, który zamierza założyć teatr. Nie znajduje jednak wsparcia u kolegów i koleżanek skoncentrowanych na planowaniu przyszłych karier i ponosi fiasko.

Falstart był moją bardzo szczerą i pewnie trochę naiwnie maksymalistyczną próbą rozliczenia się z WGIK-iem. Film rozwścieczył ówczesnego rektora. Naciskał, żeby usunąć scenę finałową. Kiedy nie wyraziłem zgody, zniknął jej negatyw. Zduplikowałem go z kopii roboczej. Na dzień przed obroną dyplomu decyzją rektora został zdjęty mój promotor Andriej Smirnow, wspaniały reżyser i jeden z największych w ZSRR „półkowników”. Dostałem promotora $\mathrm{z}$ urzędu, który chyba pomylił rolę $\mathrm{i}$ - jak się okazało następnego dnia - przemawiał tonem prokuratora.

W roku 1980 przyszły dokumentalista asystuje Krzysztofowi Zanussiemu podczas realizacji filmu Constans. Drygasa fascynuje metoda pracy autora Struktury kryształu, w dużej mierze oparta na improwizacji i otwartych dialogach, dająca, co istotne ze względu na późniejsze twórcze preferencje Drygasa, efekt niemal paradokumentalny[2]. Również problematyka poruszana $\mathrm{w}$ dziele Zanussiego wydaje się z perspektywy późniejszych filmów Drygasa szczególnie bliska adeptowi reżyserii:

[1] Wszystkie cytaty, jeśli nie zaznaczono inaczej, pochodzą z autoreferatu wygłoszonego przez Macieja Drygasa podczas kolokwium habilitacyjnego, które odbyło się na Wydziale Reżyserii PWSFTviT w Łodzi 17 maja 2012 roku.

[2] Metodą aktorskiej improwizacji powstały filmy Za ściana (1971) i Stan posiadania (1989). Zanussi

\section{Sztuka opowiadania historii}

odwołuje się do niej również w innych filmach w pracy nad pojedynczą rolą, poszczególnymi scenami. Reżyser mówi o improwizacji w wywiadzie-rzece, którego udzielił Idze Czarnawskiej. Krzysztof Zanussi. Sylwetka artysty, rozm. I. Czarnawska, Warszawa 2008, s. 118-121. 
W Constansie za pomocą obrazów filmowych autor przedstawia społeczną schizofrenię, będącą konsekwencją owego fałszu. Człowiek uczciwy w jakiejkolwiek małej społeczności realnego socjalizmu musiał czuć się niezręcznie, a ponadto jego uczciwość przybierała znamiona obłudy. Natomiast ludzie, którzy nauczyli się - kierując się instynktem samozachowawczym - w tej rzeczywistości funkcjonować, $\mathrm{w}$ istocie postawieni byli poza dobrem i złem[3].

Rok później raz jeszcze spotyka się z Zanussim na planie filmu $Z$ dalekiego kraju (1981). W momencie rozpoczęcia prac nad własnym debiutem fabularnym ma również za sobą asystenturę u Kieślowskiego podczas zdjęć do Przypadku (1981) - filmu, którego wariantywna struktura jest wprawdzie daleka od modeli narracyjnych kina faktów, ale zdarzenia i postaci w nią ujęte pozostają wyraźnie zakorzenione w rzeczywistości[4].

Pierwszy film Drygasa zrealizowany po powrocie do Polski to średniometrażowa produkcja telewizyjna Psychoterapia (rok produkcji: 1983, rok premiery: 1984). Powstaje w Zespole Filmowym Tor kierowanym przez Zanussiego.

Była to opowieść o studentce psychologii, która przekonana o swojej wiedzy prowadzi spotkania psychoterapeutyczne z rówieśnikami. Po drodze rani "pacjentów” i najbliższych. W końcu sama staje się ofiarą swoich wątpliwych etycznie eksperymentów. Scenariusz, choć wysoko oceniony w Zespole Tor, okazał się w realizacji, moim zdaniem, zbyt literacki. Miałem poważne kłopoty z przełożeniem całej, nieprostej historii na język filmu. Popełniłem mnóstwo błędów typowych dla debiutanta. W efekcie uznałem ten film za kompletną porażkę i nie oglądałem go przez blisko 30 lat.

Okruch, detal,

Metoda pracy Drygasa zaczyna kształtować się podczas przyfragment gotowań do kolejnego fabularnego projektu. Akcja Surowego klimatu miała toczyć się w roku 1881 wokół wydarzeń związanych z zabójstwem cara Aleksandra II. Młody Polak Ignacy Hryniewiecki rzucił bombę pod nogi władcy i sam od niej zginął. Dokumentacja w archiwach Moskwy i Wilna trwa blisko rok. Pomiędzy skrupulatnie zebranymi faktami pozostaje margines - miejsce na kreację.

Natknąłem się wtedy na notatkę służbową carskiej ochrany zawierającą suchą informację, że chcąc ustalić tożsamość zamachowca, głowę carobójcy przedstawiono studentom Instytutu Technologii w Petersburgu... Ten krótki dokument stał się dla mnie inspiracją do wykreowania całkowicie fikcyjnej postaci śledczego Woronowa, który z głową umieszczoną w słoju $\mathrm{z}$ formaliną objeżdża Rosję, chcąc ustalić nazwisko carobójcy. Stworzenie postaci Woronowa całkowicie przewartościowało pomysł scenariusza. Śledczy stał się pełnokrwistym bohaterem mojej historii, ponurym i tragicznym.

[3] M. Marczak, Niepokój i tęsknota. Kino wobec wartości. O filmach Krzysztofa Zanussiego, Olsztyn 2011, s. 234.

[4] Warto odnotować, że owo zakorzenienie w rzeczywistości nie ogranicza się do uczynienia istotnych wydarzeń historycznych (jak Czerwiec 1956 czy Marzec 1968) przełomami w biografii głównego bohatera. Polega również na wyprowadzeniu postaci drugoplanowych, jak Werner z pierwszej części Przypadku, z tekstów reporterskich. Szerzej na ten temat zob. K. Mąka-Malatyńska, Krall i filmowcy, Poznań 2006, s. 41-55. 
Ze względów politycznych projekt nie zostaje zrealizowany. Sposób pracy nad nim pokazuje jednak istotę kształtowanej przez Drygasa metody dokumentalnej. Jej podstawę stanowi szczegółowa, „głęboka dokumentacja”, związana najczęściej z wielomiesięczną kwerendą w archiwach filmowych, przeglądaniem tysięcy metrów taśmy filmowej, przesłuchiwaniem setek godzin nagrań. Punktem wyjścia, zalążkiem pomysłu jest zwykle szczegół, okruch lub ślad jakiegoś zdarzenia przeradzający się w detal scenariuszowy - przedmiot, fragment nagrania, wokół którego Drygas buduje historię, tworzy napięcie emocjonalne. Ów detal sprawia, że opowiadane przez niego historie nabierają głębokiego humanistycznego sensu.

W kolejnym po Surowym klimacie fabularnym projekcie Grecka wyspa funkcję taką pełnią klucze do domów ściskane w dłoniach greckich kobiet ewakuowanych w okresie wojny domowej w roku 1949 do Polski:

Wśród donosów, anonimów oraz pisanych polskimi kulfonami listów dzieci do Bieruta z prośbą o odnalezienie brata czy siostry, którzy podczas tych przesiedleń zostali wysłani gdzie indziej, natknąłem się na pozbawiony emocji, suchy raport opisujący kolejny transport Greków. Ludzi tych przywieziono rumuńskim statkiem handlowym. Była to grupa strasznie wynędzniałych kobiet i mężczyzn. Kobiety bezskutecznie usiłowano namówić na kąpiel. W końcu siłą zdarto z nich brudne, zawszone ubrania i zaprowadzono pod prysznic. Stały tam i trzymały coś w zaciśniętych dłoniach. Kiedy pytam moich studentów, cóż to mogło być, najczęściej odpowiadają: krzyżyk, woreczek ziemi, kamień, fotografia. A one ściskały w dłoniach klucze od swoich greckich domów. Nie znajduję bardziej przejmującego szczegółu, który ilustrowałby stan duchowy tych kobiet i wieczną nadzieję, że kiedyś powrócą do swoich miejsc.

Również ten scenariusz ze względów politycznych nie zostaje skierowany do produkcji[5]. Doświadczenia fabularne stają się jednak istotną częścią warsztatu dokumentalisty:

Co łączy te oba gatunki - fabularny i dokumentalny? Po pierwsze - dokumentacja. Pracując nad scenariuszami fabuł, miałem już za sobą doświadczenie potężnych dokumentacji. Na przykład do scenariusza Surowy klimat, który dotyczył zabójstwa cara Aleksandra II, spędziłem wiele miesięcy w archiwach i bibliotekach. W Greckiej wyspie, która rozgrywała się w obozie dla dzieci przywiezionych do Polski w 1949 roku, podczas wojny domowej w Grecji, jeździłem po całym kraju, usiłując odnaleźć tych, którzy przeszli przez ten koszmar. Już wtedy bardzo bliska była mi zasada podążania drogą od faktu do kreacji. A więc najpierw usiłowałem bardzo szczegółowo dowiedzieć się, jak było naprawdę. Po to, żeby zbudować fundament, na którym później powoływałem do życia swoich bohaterów.

Druga rzecz, którą zaadoptowałem z fabuły do filmu dokumentalnego, to myślenie konstrukcją i dramaturgią. Znajdowanie dramaturgicznego

[5] Scenariusz ukazał się na łamach miesięcznika „Dialog”. M. Drygas, Grecka wyspa. Scenariusz filmo-

$w y$, „Dialog” 1990, nr 6, s. 5-31. 
klucza, który uniesie historię na wyższe piętra znaczeniowe i emocjonalne. No i powściągliwość i celowość w poszukiwaniu formy. Idąc tym tropem, w końcu doszedłem do wniosku, że granica pomiędzy filmem fabularnym a dokumentalnym jest dość wątła.

Pod koniec lat 8o. rodzi się pomysł pierwszego w dorobku Drygasa filmu dokumentalnego - opowieści o Ryszardzie Siwcu, który 8 września 1968 roku dokonał aktu samospalenia na Stadionie Dziesięciolecia na znak protestu przeciwko inwazji wojsk Układu Warszawskiego na Czechosłowację. I tu znów punktem wyjścia staje się strzęp pamięci - zaledwie siedmiosekundowy fragment zarejestrowany podczas uroczystości dożynkowych na stadionie, który przez dziesięciolecia spoczywał na półkach archiwum w puszce z napisem „Płonący człowiek"[6]. Powstaje złożony, pełen symboli i przesycony hipnotyzującą muzyką Pawła Szymańskiego obraz zbiorowej amnezji. W recenzji publikowanej po pokazie filmu w Łagowie podczas Lubuskiego Lata Filmowego Andrzej Werner pisze:

Dawno, bardzo dawno nie widziałem filmu, który wywarł na mnie podobnie wstrząsające wrażenie jak czterdziestominutowy dokument Macieja Drygasa Ustyszcie mój krzyk. [...] Mówi o trwającym dwadzieścia kilka lat milczeniu. Kilkadziesiąt tysięcy ludzi to widziało i nie zobaczyło, nie chciało czy raczej nie mogło usłyszeć tego głosu[7].

Realizacja Usłyszcie mój krzyk przebiega równolegle z pracą nad słuchowiskiem Testament dla Polskiego Radia. Jest to pierwszy kontakt Drygasa ze światem radia:

Bardzo długo nie mogłem znaleźć klucza dramaturgicznego, który otworzyłby mi drzwi do formy radiowej. Trwało to kilka miesięcy, podczas których nie potrafiłem się uwolnić od konstrukcji filmu. Przyczepiałem do tablicy magnetycznej miniaturowe karteczki z opisanymi scenami, przestawiałem je z miejsca na miejsce i za każdym razem czułem, że powtarzam drogę, po której już szedłem. Byłem bliski rezygnacji, gdy w końcu przyszło olśnienie. Wlepiłem wzrok w tablicę magnetyczną i zacząłem jeszcze raz tłumaczyć sobie film: Usłyszcie mój krzyk jest w gruncie rzeczy opowieścią o nas, o kondycji naszego społeczeństwa. Świadkowie, którzy na Stadionie Dziesięciolecia odwracali się plecami do płonącego Siwca, po latach usiłują racjonalizować swoje zaniechanie. O tym już opowiedziałem, więc po co tu wiszą te kartki? Zerwałem raz na zawsze relacje świadków i wyrzuciłem do kosza. I spojrzałem na to, co pozostało. Porozrzucane karteczki z wypowiedziami najbliższej rodziny i fragmenty posłania Ryszarda Siwca. Jego słowa brzmiały niczym testament. Wróciłem do wszystkich rodzinnych nagrań i krok po kroku zacząłem budować historię wokół relacji Siwca, jako ojca i męża, z żoną i dziećmi. Tak powstała konstrukcja słuchowiska

[6] Scenariusz słuchowiska oraz eksplikacja autorska zostały opublikowane na łamach „Kwartalnika Filmowego". J. Tischner, Myśmy tej śmierci nie przemyśleli, wypowiedź nagrana przez Macieja Drygasa podczas dokumentacji, „Kwartalnik Filmowy” 1993, nr 1, s. 41-43; M. Drygas, „Usłyszcie mój krzyk”. Lista montażowa, ibidem, s. 44-59; M. Drygas, Było wtedy ostre słońce... Jak powstawał film o Siwcu, ibidem, s. 63-67; M. Drygas, Testament. Stuchowisko dokumentalne, ibidem, s. 69-83. Obszerne autorskie omówienie filmu zamieszczamy na następnych stronach niniejszego numeru „Images”.

[7] A. Werner, Nikt nie ustyszał, „Kino” 1991, nr 12, s. 6. 
dokumentalnego pod tytułem Testament - opowieści o krzyżu, który rodzina Siwca będzie dźwigała do końca życia.

Pamiętam, że kiedy pojawiłem się pierwszego dnia w studiu radiowym, żeby rozpocząć prace nad montażem, czułem się całkowicie zagubiony. Z niepokojem rozglądałem się, gdzie jest ekran! Jak powołać do życia świat bez obrazu? Chcąc się jakoś odnaleźć w tym kompletnie dla mnie obcym terenie, włączyłem swoje myślenie filmowe. Szybko zrozumiałem, że dźwięk rozpięty pomiędzy dwiema kolumnami głośnikowymi daje się - podobnie jak obraz - ułożyć w bliskich i szerokich planach, że rozstawiając poszczególnych bohaterów bardziej z prawej lub lewej strony, można ułożyć geografię miejsca. I wtedy przyszło mi do głowy, że to, co robię, jest w rzeczywistości realizacją filmu dokumentalnego dla niewidomych. Brzmi to paradoksalnie, jednak to moje bardzo osobiste odkrycie uchyliło mi nowe, nieznane dotąd wrota do niezwykłej krainy, w której można malować obrazy dźwiękiem, budować całkiem widzialny świat, wykorzystując scenografię dźwiękową. To pierwsze doświadczenie radiowe bardzo mocno odcisnęło się w mojej świadomości. Niezwykły świat dźwięków zaczął mnie coraz bardziej pociągać i fascynować.

Wkrótce powstają kolejne słuchowiska dokumentalne[8] Macieja Drygasa. Równolegle z filmem Stan nieważkości (1994) realizuje dokument radiowy Być w kosmosie:

Dramaturgia rozpięta była na trzech równoległych osiach czasowych, które tworzyły układ nowelowy. Przeżycia kosmonautów zderzone zostały z kontekstem historycznym. Od radości z udanej misji pierwszego radzieckiego sputnika do zwątpienia i rozczarowania końcem pewnej epoki, rozpadającym się systemem.

Inspiracją dla obu utworów jest informacja o kosmonaucie Siergieju Krikaliowie, który krąży samotnie po orbicie w stacji Mir. Podczas jego lotu świat przeszedł głębokie zmiany: przestaje istnieć Związek Radziecki, w europejskich demoludach dochodzi do zmian ustrojowych. Tymczasem, jak donoszą media, Krikaliow mógł nigdy nie wrócić na Ziemię. Na stacji kończą się zapasy żywności. Sytuacja staje się krytyczna. „Pomyślałem, że ten dramatyczny lot jest bardzo interesującym pretekstem do zbudowania dokumentalnej opowieści o końcu dwudziestego wieku". Długotrwała dokumentacja w Rosyjskim Centrum Dokumentacji Kosmicznej oraz w Instytucie Problemów Medyczno-Biologicznych w Moskwie i długie rozmowy z kosmonautami niemal całkowicie zmieniają pierwotny projekt, przede wszystkim zostaje zweryfikowane wyobrażenie o życiu kosmonautów zbudowane na bazie doniesień medialnych.

[8] Szerzej na temat słuchowiska dokumentalnego zob. M. Drygas, Wyzwolić wyobraźnię, w: Biblia dziennikarstwa, red. A. Skworz, A. Niziołek, Kraków 2010, s. 307-308. Kategorię słuchowisk dokumentalnych wyodrębnia również Sława Bardijewska: „Przykładem form dokumentalnych są utwory kolażowe Jerzego Tuszewskiego, oparte na dokumentach rejestrowa-

\section{Dźwiękowy obraz świata}




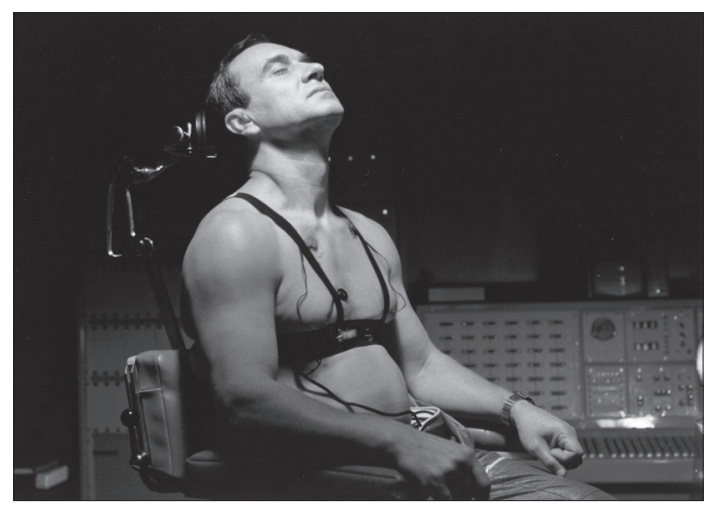

Uzbroiłem się w masę ciężkich egzystencjalnych pytań i wyruszyłem do Moskwy. Spotkałem się z Krikaliowem tuż po tym, jak opuścił kwarantannę. Byłem przekonany, że ujrzę człowieka psychicznie zrujnowanego. A tu uśmiechnięta twarz. Ja pytam o samotny lot, a on się dziwi i mówi, że to jakaś bzdura, że oni w stacji orbitalnej nigdy nie latają w pojedynkę. Więc tłumaczę, że przecież gazety, telewizja, słowem cały świat martwił się o jego los. A on rozkłada ręce i opowiada mi jakąś kompletnie inną historię. Owszem, za jego zgodą przedłużono mu lot o pół roku, a w tym czasie zmienili się jego partnerzy, cała reszta to dziennikarska kaczka. Po tej rozmowie długo zastanawiałem się, co mam dalej począć. Racjonalną

Kadr z filmu Stan nieważkości, reż. Maciej J. Drygas, 1995. decyzją byłby powrót do domu, bo przecież runął mój pierwotny pomysł. Zwyciężyła ciekawość, na początku czysto ludzka, czyja wersja tego lotu jest prawdziwa.

Reżyser wysłuchuje setek nagrań rozmów pomiędzy pracownikami Centrum Kierowania Lotami a kosmonautami ze stacji orbitalnej. Okazuje się, że w zaskakujący sposób wdzierała się do nich rzeczywistość, odczuwane w codziennym życiu konsekwencje gwałtownych zmian społeczno-politycznych. Pieczołowicie wyselekcjonowany materiał uzupełniają przeprowadzone tu i teraz rozmowy reżysera z kosmonautami:

Po pierwszych rozmowach podzieliłem ich [kosmonautów - przyp. K.M.-M.] na dwie kategorie: żołnierzy i poetów. Żołnierze to ci, którzy lecieli w kosmos, żeby się dobrze ustawić do końca życia: Order Bohatera ZSRR, mieszkanie, samochód. Poeci wyruszali tam z wewnętrznej głębokiej potrzeby, determinacji, ciekawości. Żołnierze wypełniali kolejne przewidziane planem punkty, posłusznie realizowali kolejne eksperymenty i z ulgą wracali na Ziemię. Chętnie opowiadali o codziennym życiu w stacji orbitalnej Mir, a jedyna bardziej ogólna refleksja, którą się równie chętnie dzielili, dotyczyła Ziemi, że taka malutka i chrupka i że należałoby zabrać w kosmos polityków, bo wtedy być może złagodnieliby i nie rzucali na nią tylu bomb. Poeci przeżyli tam dużo więcej i głębiej, ale pilnie strzegli swoich tajemnic. Na początku traktowali mnie jak dziennikarza, który przychodzi na wywiad. Kilka szybkich pytań i koniec. A ja słowo „wywiad” już dawno wykreśliłem ze swojego leksykonu. Chciałem się z nimi umówić na rozmowę. Chciałem otrzeć się o ich tajemnicę, chciałem zrozumieć, co naprawdę czuli, obcując z nieskończonością kosmosu. To przedzieranie się przez ich skorupę nie było łatwe. Kosmonauci nawet w rozmowach prywatnych nie dotykają tych spraw. To jest ich najbardziej intymna sfera. Rozmawiałem z nimi wielokrotnie, zataczając kolejne kręgi.

\section{Po premierze filmu recenzent „Kina” pisał:}

Stan nieważkości wydaje się zaprzeczać wszelkim regułom filmu dokumentalnego. Większość czasu projekcji wypełniają gadające głowy, ale - trochę jak w Czerwonym [filmie fabularnym w reżyserii Krzysztofa Kieślowskiego - przyp. K.M.-M.] - widz dopiero w wiele godzin później orientuje się, 
iż istotnie dużo mówiono. Bo przecież nie chodzi ani o ustawienia kamery, ani o montaż, ale o to, co zostało powiedziane[9].

Materiał dźwiękowy stanowi niezwykły zapis czasu, dokonany ze szczególnego punktu widzenia. Jest to świat dźwięków, które należało wypełnić obrazem. Reżyser postanawia sprawdzić plotkę o materiałach filmowych przechowywanych w piwnicach Instytutu Medycyny Kosmicznej w Moskwie. Gdy po długich staraniach udaje mu się w końcu do nich dotrzeć, okazuje się, że puszki zawierają ponad sto tysięcy metrów taśm:

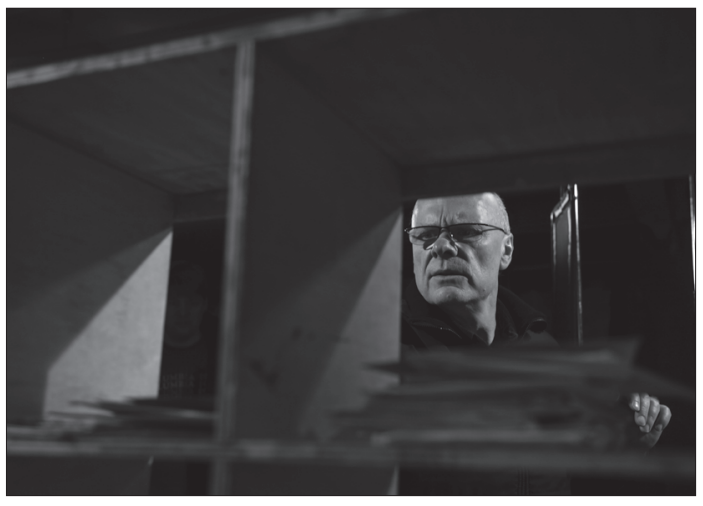

Pomyślałem, że jeśli znajdę choć kilka sekund, tak jak to było w Usłyszcie mój krzyk, gdy odnalazłem siedmiosekundowe ujęcie płonącego Ryszarda Maciej J. Drygas podczas prac nad filmem Cudze listy, 2010. Siwca, to mój trud nie pójdzie na marne. Wkrótce odkryłem unikalne, nigdy nie emitowane materiały z zarejestrowanymi eksperymentami na ludziach i zwierzętach. Pośród nich było między innymi poruszające ujęcie wirującej małpy, które później stało się jednym z mocniejszych elementów kompozycyjnych filmu.

Doświadczenia w pracy nad słuchowiskami Testament i Być $w$ kosmosie skłaniają Drygasa do podjęcia próby zrealizowania całkowicie niezależnego, nie związanego z żadnym projektem filmowym, przedstawienia radiowego. W roku 2001 powstaje słuchowisko Moja góra, które staje się dla reżysera szczególnym obszarem eksperymentu. Czym jest „obraz dźwiękowy”? Jak budować „dźwiękową scenografię"? Jako filmowiec wciąż szuka analogii pomiędzy kinem a sztuką radiową[10], by w końcu stworzyć za pomocą dźwięku przejmującą opowieść o doświadczaniu gór. Prosi wybitnego polskiego himalaistę Piotra Pustelnika, by nagrywał swoisty dziennik podczas kolejnych wypraw. Gdy bohater oswaja się już z nową dlań sytuacją, co następuje dopiero po kilku ekspedycjach, Drygas otrzymuje materiał niezwykły:

Moment przełomowy nastąpił w trakcie wyprawy na Broad Peak w Karakorum. Podczas wspinaczki Pustelnikowi pękła lina poręczowa. Himala-

[9] P. Lis, Powrót z gwiazd, „Kino” 1994, nr 10, s. 5-6. [10] Warto odnotować, że próby poszukiwania związków pomiędzy słuchowiskiem radiowym a filmem pojawiały się $\mathrm{w}$ refleksji nad sztuką radiową już w latach 30. Antoni Bohdziewicz na łamach czasopisma „Pion” określał radio jako kino dla ucha. Idem, Przyszłość stuchowiska radiowego, „Pion” 1935, nr 15. Choć w polskiej refleksji nad słuchowiskiem dominuje wyraźnie orientacja logocentryczna, to co jakiś czas powraca w niej wątek związków pomiędzy sztuką radiową a kinem. Joanna Bachura, rozważając składniowe problemy w słuchowisku radiowym, wychodzi od semiotycznej teorii kina Jurija Łot- mana (Semiotyka filmu, przeł. J. Faryno, T. Miczka, Warszawa 1983). Znajduje analogie pomiędzy kadrem filmowym a słowem w słuchowisku. $\mathrm{W}$ opinii autorki odbiorca radiowy nie jest w stanie wyodrębnić łączeń montażowych. Kolejną jednostką w słuchowisku byłaby więc scena. „Słuchowisko nie dzieli się na akty, ale na sceny/szeregi scen, co niewątpliwie dostarcza kolejnego argumentu na związek słuchowiska $\mathrm{z}$ filmem i odrębność słuchowiska w stosunku do teatru scenicznego" (s. 229). J. Bachura, Odsłony wyobraźni. Wspótczesne stuchowisko radiowe, Toruń 2012, S. 226-251. 
ista zaczął się staczać po lodowcu, który kończył się urwiskiem. Nabierał prędkości, nie był w stanie się zatrzymać, zrozumiał, że to koniec. Nagle, pięćdziesiąt metrów od przepaści, przypadkiem zahaczył o kamień. Potwornie się potłukł, ale dzięki temu się zatrzymał. Gdy się doczołgał do swojego namiotu i zrozumiał, że cudem ocalał, włączył magnetofon i zaczął nagrywać relację ze swojego spadania. Sekunda po sekundzie opisywał ten stan, kiedy człowiek żegna się z życiem. Od tego momentu Piotr Pustelnik zaczą komunikować się z magnetofonem, jakby rozmawiał z kimś bliskim. Były to bardzo osobiste relacje, często przepełnione goryczą i wątpliwościami. To było zmaganie się z sobą samym, z własną fizjologią, niemocą, pełne pokory i szacunku wobec Góry.

I znów brakowało elementu, który dopełni słowo. Tym razem nie może to być jednak obraz, lecz tło akustyczne, owa „dźwiękowa scenografia”. Zbudowanie jej z realistycznych efektów wydaje się twórcy pewnym uproszczeniem, sprowadzeniem tła do funkcji ilustracyjnej. By nadać historii dodatkowe znaczenia, by stworzyć sens metaforyczny, stosuje dźwięki odkryte przypadkowo:

Miałem ultrasonograficzne badanie serca. Lekarz nie wyłączył głośnika i nagle, ku swojemu zdumieniu, usłyszałem się jakby od środka. Rytmiczny dźwięk otwierających się zastawek nie ma nic wspólnego z biciem serca, do jakiego przywykliśmy, oglądając filmy fabularne. Przesunięcie sondy nawet o milimetr generuje zupełnie inne dźwięki. To jest wielka, tajemnicza, niezwykła symfonia.

Dodatkowo nagrywa przez aparat Dopplera szum płynącej krwi. Tak zebrany materiał wymaga konstrukcji dramaturgicznej, która wychodziłaby poza schematyczną opowieść o wspinaczce. Pracując nad nią, reżyser odwołuje się do klasycznej dramaturgii filmu fabularnego: opiera opowieść na dwóch punktach zwrotnych. W jednej trzeciej filmu bohaterowie przeżywają radość z wejścia na szczyt. I teraz dopiero rozpoczyna się dramat lęku, wątpliwości, śmierci. Drygas odwołuje się do doświadczenia samotnego wejścia Pustelnika na Makalu i pozostawia swego bohatera na kilkadziesiąt metrów przed szczytem, w drugim punkcie zwrotnym opowieści:

Po nim odezwała się już tylko Góra, całą swoją mocą, nie dając himalaiście najmniejszej szansy na zdobycie szczytu. Odezwała się mocą pełnego składu orkiestry symfonicznej, dla której muzykę napisał wybitny kompozytor Paweł Szymański. [...] Ta muzyka długą, monumentalną uwerturą otwiera moje słuchowisko, by potem rozlać się pod pierwszymi wypowiedziami himalaistów. Pod koniec sekwencji zaczyna niepokojąco pulsować. Szymański zastosował tutaj dość skomplikowany zabieg techniczny. Przepuścił końcowy fragment muzyki przez obwiednię fali dźwiękowej zaczerpniętej z nagrań mikrokosmosu mojego ciała, stąd muzyka zaczyna się dławić rytmem mojego serca. To dało bardzo dziwny, niepokojący efekt. Tak monumentalnie skomponowana muzyka wydatnie wpłynęła na wizualną stronę słuchowiska. Ma się takie wrażenie, jakby himalaiści, którzy opowiadają o swoich doznaniach, stali u podnóża wielkiej góry i spoglądali na jej wierzchołek. A przecież te rozmowy nagraliśmy w Warszawie. 
Z doświadczenia radiowego rodzi się kolejny projekt filmowy dokument o radiowcach. Głos nadziei (2002) opowiada o Radiu Wolna Europa, o znaczeniu tej stacji dla Polaków w czasach PRL-u, o pracownikach RWE oraz o tych funkcjonariuszach, którzy zajmowali się zagłuszaniem nadawanych przez stację programów. Chociaż Drygas znów podejmuje temat związany z nieodległą historią Polski, jego film, podobnie jak Usłyszcie mój krzyk, wymyka się sztampie charakterystycznej dla dokumentu historycznego:

Dosłownie w ostatnim momencie udało mi się sfilmować pola antenowe emitujące fale krótkie. To właśnie z tych pól niegdyś płynęły, niezwykle uciążliwe dla słuchaczy RWE, modulacje zagłuszające. W ostatniej chwili zdążyłem również zarejestrować likwidację masztów antenowych w Radiówku pod Warszawą. Kiedy spojrzałem na te materiały, na których widać potężne, padające ze świstem maszty, wiedziałem, że mam już finał filmu. Myśląc o wizualnej stronie, podzieliłem przestrzeń w moim filmie na dwa światy: pod drutami anten zagłuszających, gdzie toczyło się życie codzienne w PRL, oraz wolnego obszaru ponad masztami, gdzie w kłębiastych chmurach rozchodziły się niedostrzegalne fale eteru.

Nagrania audycji radiowych poddaje przetworzeniu. Wykorzystuje autentyczne modulacje zagłuszające, które wzmacnia w momentach, gdy spiker RWE instruuje, jak zbudować anteny poprawiające jakość odbioru programów. Udaje się w ten sposób nie tylko zbudować dramaturgiczne napięcie, ale również nadać opowieści znaczenie metaforyczne, uniwersalne. Prawda nie daje się zagłuszyć.

Szczególnie jest plastyczny leitmotiv - widok chmur i przezierających pod nimi strzępów polskiego pejzażu. Naturalnym środowiskiem wolnego słowa stają się tu przestworza, nie tylko dlatego, że unoszą je radiowe fale, ale może i po to, by dla dramatycznych zmagań dziejowych o najwyższej wartości zasygnalizować również metafizyczny układ odniesienia[11].

Usłyszcie mój krzyk i Głos nadziei to dwa filmy, które otwierają tetralogię o PRL-u. Kolejne - Jeden dzień w PRL i Cudze listy - powstają w roku 2005 i 2010. Oba traktują o codzienności w państwie totalitarnym, codzienności poddanej permanentnej kontroli i interwencjom opresyjnej władzy. Przez pięć lat Drygas rekonstruuje za pomocą archiwaliów jeden dzień - 27 września 1962 roku, w którym nie wydarzyło się nic szczególnego. Na mozaikowy obraz tego dnia składają się również listy, pamiętniki, zapiski osób prywatnych. Na obraz oficjalny, przekazywany przez ówczesne media, nakłada się pamięć prywatna. W historycznych dokumentach reżysera historia oficjalna spotyka się $\mathrm{z}$ historią prywatną, pamięć zbiorowa $\mathrm{z}$ osobistą.

Penetrowałem archiwa z materiałami filmowymi. Interesowały mnie obrazy z życia codziennego z lat 60 . Nawiązałem również kontakty z byłymi filmowcami amatorami. Wkrótce wyruszyłem w Polskę z dwoma przeglądarkami

[11] T. Szyma, Stowa w przestworzach, „Kino” 2002,

nr 12, s. 22. 

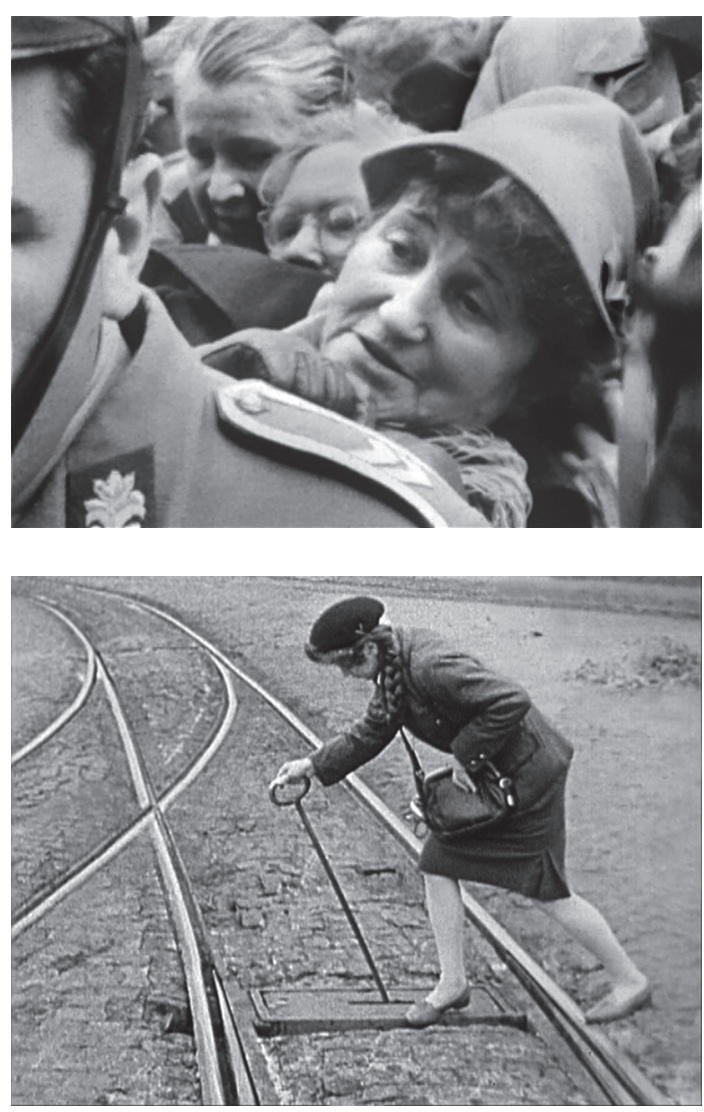

Kadry z filmu Jeden dzień w PRL, reż. Maciej J. Drygas, 2005. na korbkę, do taśmy $16 \mathrm{~mm}$ i $8 \mathrm{~mm}$. Kręciłem moją korbką w prywatnych mieszkaniach, domach kultury, gdzie kiedyś mieściły się amatorskie kluby filmowe, w piwnicach, w których często lądowały po latach niepotrzebne nikomu materiały. Ta praca przypominała robotę archeologa. Tylko zamiast przekopywać tony piachu, ja przerzucałem tysiące teczek $\mathrm{z}$ dokumentami, przeglądałem tysiące metrów taśmy filmowej. Pracując nad tym projektem, wszedłem w stan, który umownie nazywam dokumentacją permanentną. A wszystko po to, żeby poprzez doświadczenie tego jednego dnia, poprzez mikroobserwacje ludzkich losów, ludzkich pragnień i namiętności, ludzkiego bólu i cierpienia, zderzonych z potężną siłą biurokratycznego i represyjnego państwa, stworzyć dokumentalny fresk, który na metaforycznym poziomie miał ułożyć się w portret wewnętrzny Polaków.

W Jednym dniu w PRL Drygas prowadzi swoistą grę z prawdą. Wiele ze zgromadzonych materiałów brzmi niewiarygodnie, nieprawdopodobnie, a jednak są prawdziwe. Narrację zza kadru złożoną również z zapisków i dokumentów odczytują w filmie nie aktorzy, lecz naturszczycy, nadając jej szczególny walor prawdy. Reżyser przy pomocy studentów z Laboratorium Reportażu nagrywa mieszkańców wsi i miasteczek. Osiem miesięcy trwa proces montażu materiałów, nad którym czuwa Katarzyna Maciejko-Kowalczyk. Powstaje obraz jednego dnia od świtu do zmierzchu, a jednocześnie swoista mozaika, przekrój przez różne grupy i warstwy społeczne.

Drygas wybiera to właśnie, czego się nie dostrzega, bo jest zbyt zwyczajne, oczywiste, wyparte z pamięci przez potok zdarzeń ważniejszych, konstruowanych przez własną, prywatną pamięć, ale i zinstytucjonalizowane mechanizmy, które nią w dużym stopniu sterują. Wówczas pamięć była schronieniem i szkatułką, w którą wkładało się to, co nieoficjalne, co nie może się znaleźć w gazetach[12].

Tetralogię o PRL-u zamyka film Cudze listy (2010). Osią dramaturgiczną dokumentu stają się prywatne listy pisane w komunistycznej Polsce, które były przedmiotem zainteresowania służb perlustracyjnych.

Praca nad tym projektem trwała wiele lat $\mathrm{z}$ poczuciem, że będzie to już mój ostatni film dotykający czasów minionej epoki, moje pożegnanie $\mathrm{z}$ tematyką PRL-u.

[12] A. Werner, Jeden dzień w PRL, w: Polska Szkoła Dokumentu. Maciej Drygas, red. serii T. Sobolewski, Warszawa 2006, brak numeracji stron. 
Korespondencja ukazuje życie w systemie totalitarnym z perspektywy codzienności. Nie przedstawia historycznych zdarzeń przełomowych, choć ich echa są czytelne w wielu listach. Ponownie prywatna historia zostaje zderzona z Historią przetaczającą się przez ziemie naszego kraju. Z listów wyłania się obraz ubogiego życia obywateli, w które nieustannie i na każdym poziomie ingeruje policyjne państwo. Jego funkcjonariusze czytają prywatne listy, podsłuchują, wiedzą o obywatelach wszystko, docierają do najbardziej intymnych szczegółów. Drygas postanawia ponownie odwołać się do konwencji zastosowanej w Jednym dniu w PRL: jako lektorów zatrudnia naturszczyków, dzięki czemu udaje mu się zbudować przekaz niezwykle wiarygodny. Narracji zza kadru towarzyszą ujęcia $\mathrm{z}$ filmów dokumentalnych oraz z krótkometrażowych fabuł z czasów PRL. Lejtmotyw stanowią obrazy ukazujące dłonie sprawnie otwierające koperty i trzymane nad parą listy[13]. Marek Hendrykowski pisze o filmie:

Rzecz jednak w tym, że w PRL istniał rozbudowany system ich [prywatnych listów - przyp. K.M.-M.] potajemnego czytania. Aby poznać morfologię funkcjonowania tego systemu, twórca filmu Cudze listy wsłuchuje się z uwagą w indywidualną zawartość poszczególnych przekazów, poświęcając im maksimum osobistej empatii. Każda z tych spraw miała przecież swój głęboko ludzki wymiar. Dzięki współczującemu nastawieniu autora całość blisko godzinnego filmu dokumentalnego nie robi wrażenia bezdusznego rejestru (śmiertelnie nudnego przeglądania zakurzonych archiwalnych teczek) czy katalogu epistolarnych rekwizycji. Wprost przeciwnie, kontakt z tą korespondencją pozwala widzowi wniknąć za pośrednictwem oglądanego dokumentu w istotę samego procederu. [...] Montażowy film Drygasa przejawia zadziwiającą ekspresję wynikającą z głęboko przemyślanej metaforyzacji ekranowego świata. W miarę upływu czasu poruszany w nim temat staje się coraz mniej matrycą zbiorowej pamięci, a coraz bardziej tworzywem służącym do zbudowania własnej autorskiej wizji PRL[14].

Metodę permanentnej dokumentacji i detalu scenariuszowego Drygas stosuje nie tylko w filmach dotyczących przeszłości Polski. W 2005 roku po raz pierwszy wyjeżdża z kamerą do Afryki. Punktem wyjścia dwóch kolejnych filmów staje się krótka informacja usłyszana w radiu. Wybitny polski archeolog Bogdan Żurawski mówi o misji polskich archeologów w Sudanie. Na Nilu planowano budowę ogromnej tamy, która miała spowodować powstanie sztucznego jeziora o długości $170 \mathrm{~km}$. Kolebka cywilizacji miała zostać częściowo zalana wodą. Archeolodzy, historycy sztuki, etnografowie ruszyli do Sudanu, by ocalić okruchy przeszłości.

Poczułem jakąś bliskość z tym światem. Filmy dokumentalne, które dotychczas zrealizowałem, też miały znamiona swoistej archeologii. Powoływałem do życia światy, które już nie istniały. [...] Pomyślałem, że pod bezkresnymi

[13] Autorskie omówienie filmu zostało zamieszczone na następnych stronach niniejszego numeru „Images”.
[14] M. Hendrykowski, Tajemnica korespondencji. O „Cudzych listach” Macieja J. Drygasa, „Images" 2012, nr 19, s. 7-8.

\section{Archeologia odległych krain}




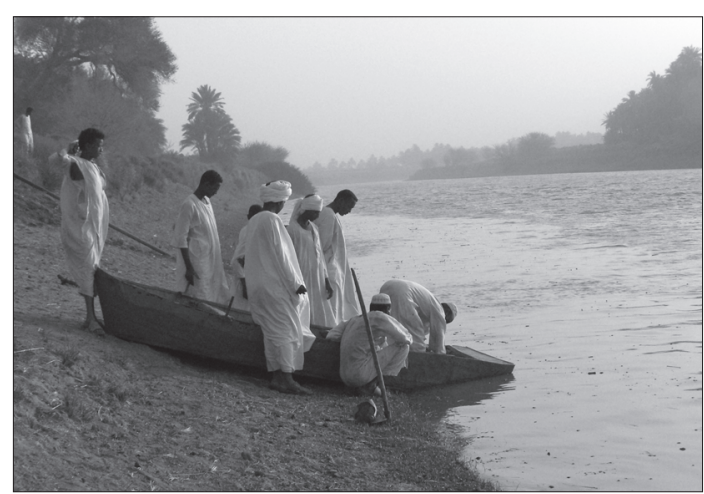

połaciami pustynnego piachu musiały wymieszać się świadectwa życia człowieka z czasów paleolitu, starożytnego Egiptu, wczesnego chrześcijaństwa, islamu. Stanęly mi przed oczyma archiwalne obrazy z budowy tamy asuańskiej, gdzie przenoszone były z miejsca na miejsce całe świątynie. Oczyma wyobraźni widziałem wystudiowane ujęcia hektolitrów wody przelewającej się przez grobowce. A przedtem sekwencje $\mathrm{z}$ archeologami, którzy te grobowce wykopują spod piachu. Po to, żeby za chwilę zalała je woda. Będę obserwatorem świata, który znika na naszych oczach! Marzyły mi się zdjęcia podwodne i z helikoptera. Słowem, miałem już w głowie ułożony cały film!
Kadr z filmu Abu Haraz, reż. Maciej J. Drygas, 2012, fot. Andrzej Musiał.

Pierwotne założenia szybko jednak zostają zweryfikowane. Długa przeprawa przez Nil pozwala reżyserowi otworzyć się na rzeczywistość, „schować swój biały świat do plecaka”. W centrum jego zainteresowania znajdują się zamieszkujący te tereny ludzie. Drygas powoli zaczyna uczyć się tego świata, z pokorą i cierpliwością przyglądając się afrykańskiemu życiu. Polscy archeolodzy umieścili swą bazę w malutkiej wiosce Abu Haraz. To tam zatrzymuje się Drygas. Na obraz pracy grupy archeologicznej stopniowo zaczyna nakładać się obraz tego, co „tu i teraz”, na zamierzchłą przeszłość - teraźniejszość wioski, której mieszkańcy zostaną wkrótce przesiedleni, a ich domy zalane wodą. Ostatecznie powstają dwa filmy. W roku 2008 Maciej Drygas realizuje krótkometrażowy Usłysz nas wszystkich:

Przyglądając się już od blisko dwóch lat pracy archeologów na stanowiskach w okolicach IV katarakty, miałem świadomość, że film, który pragnę zrealizować, daleki będzie od codziennej rodzajowości. Dlatego postanowiłem nie lokować energii w rejestrowaniu obrazów z życia archeologów. Czułem, że wykopaliska pośrodku pustyni stanowią interesujący pretekst do zbudowania struktury zdecydowanie bardziej metaforycznej. Punktem wyjścia do uruchomienia takiego myślenia była scena, w której dłonie archeologa usiłują doczyścić czaszkę. Bardzo długie, trwające trzy i pół minuty ujęcie, podczas którego każde drapnięcie szpachlą, każdy dotyk pędzla powodował rozpad zmurszałych kości, by wreszcie czaszka zamieniła się niemalże $\mathrm{w}$ proch. [...] W tym czasie rozpoczęły się prace wykopaliskowe w miejscowości Argub. Na skraju wsi archeolodzy zainteresowali się ścianami opuszczonego obejścia, które po oskrobaniu pierwszej warstwy z glinki nilowej odsłoniło mur zbudowany z kamienia i cegły mułowej. Wkrótce okazało się, że są to ściany wczesnochrześcijańskiego kościoła. Miałem wrażenie, jakby cofnął się czas. Okutani w turbany miejscowi

Maciej Drygas podczas zdjęć do filmu Abu Haraz, fot. Andrzej Musiał. fellachowie, w tańczących na wietrze białych dżalabijach, niespiesznie przesiewający przez sita piach. Sprawiali wrażenie, jakbyśmy obserwowali sceny z życia sprzed setek lat. Namówiłem kompozytora Pawła Szymańskiego, żeby napisał muzykę do tekstów staronubijskich inskrypcji odnalezionych na ścianach kościoła w Banganarti. 
Tadeusz Sobolewski zauważa:

Punktujące obraz teksty staronubijskich inskrypcji wraz z muzyką tworzą rodzaj liturgii. Zderzają się dwa porządki pojmowania świata: materialistyczny i duchowy. Rozsypujące się pod palcami archeologów fragmenty czaszki mówią: marność. Teksty inskrypcji jakby w imieniu tych szczątków proszą: „Zlituj się, Boże... Przywódco duchów, Panie, przyjdź, objaw się, usłysz nas wszystkich!". Wszystko na darmo? Jest jeszcze trzeci znaczący wątek - miejscowych Sudańczyków. Kamera zaczyna obserwować żywych świadków wykopalisk. Jest wśród nich człowiek na osiołku, za nim stąpa na cienkich nóżkach osioł-źrebak - znikają za załomem skały. Ten pozornie błahy obraz sprawia, że rzeczywistość jest ukazana jako święta, przemieniona. Taki wniosek płynie z kontemplacji grobów[15].

Cztery lata później, po kilku kolejnych wyprawach do Sudanu, zostaje zmontowany pełnometrażowy dokument Abu Haraz (2012). Drygas rejestruje ostatnie chwile istnienia niewielkiej wioski, która już wkrótce miała zostać

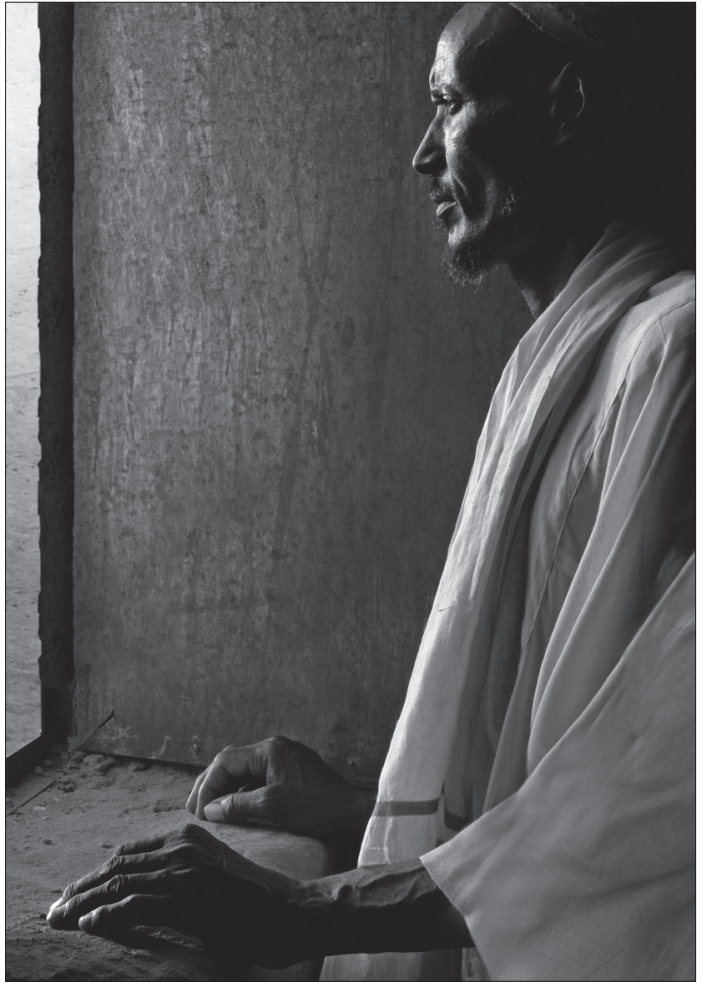

Abu Haraz, reż. Maciej J. Drygas, fot. Maciej J. Drygas. dużych fragmentów rzeczywistości w długich ujęciach budują klimat filmu o świecie, który jest, ale już za moment przestanie istnieć.

Dzisiaj moja wioska jest już 35 metrów pod wodą. Mieszkańcy Abu Haraz byli zmuszeni przenieść się do wybudowanego pośrodku pustyni miasta dla ponad 10 tysięcy ludzi. W tym mieście - getcie, wokół którego zamiast pól rozciąga się aż po horyzont tylko piach, centralnym miejscem jest sklep $\mathrm{z}$ trawą, do którego codziennie przychodzą moi bohaterowie, żeby kupić karmę dla osłów. Mężczyźni snują się po pustych ulicach, a kobiety siedzą przed telewizorami i oglądają egipskie telenowele. I tylko w nocy, w snach wracają obrazy Abu Haraz, które w porównaniu z ich nowym miejscem było naprawdę rajską krainą. Kiedy w ubiegłym roku przyjechaliśmy z operatorem kolejny raz do Wadi Mugaddam, nasi bohaterowie witali nas ze łzami w oczach. Wreszcie zrozumieli, że dzięki naszej wieloletniej cierpliwej obserwacji zachowamy pamięć o ich wiosce dla następnych pokoleń.

Drygasowi po raz kolejny udaje się zbudować obraz metaforyczny, odległy od telewizyjnych reportaży o życiu w Afryce:

Obraz życia tej wioski, symbolicznie ocalony na ekranie, nabiera cech naturalnego symbolu. Mówi wiele o naszej cywilizacji masowej, która zalewa, pochłania dawny świat wspólnotowy, samowystarczalny, w którym czas inaczej płynął. Byli uzależnieni od wylewów rzeki, nawadniającej

[15] T. Sobolewski, Swoimi słowami. Jestem wasza pamięcia, „Kino” 2013, nr 5, s. 90. 
O kinie dokumentalnym Macieja Drygasa pola o niebywałej żyzności. Zapora to wszystko niszczy. Najzwyklejsze życie pięknych ludzi z Abu Haraz oglądamy w filmie jak archeologię, coś, co przeminie[16].

Na łamach „Tygodnika Powszechnego” Michał Oleszczyk pisał:

Drygas - podobnie jak nagrodzony Oscarem amerykański dokumentalista Errol Morris, z którego filmami dorobek Polaka silnie się kojarzy - ma w sobie coś z cierpliwego archiwisty, może detektywa. [...] Drygas jest twórcą paradoksalnym, bo umiłowanie konkretu łączy z dyskretnym, ale i upartym drążeniem tematów ostatecznych. [...] Drygas jest mistrzem inscenizacyjnej i wizualnej subtelności. Proszę zwrócić uwagę na niechęć do napisów identyfikujących bohaterów: wszyscy zostają perfekcyjnie zindywidualizowani za pomocą jednego znaczącego rekwizytu. Ktokolwiek pamięta cudowne Bramy nieba (1980) Morrisa, dostrzeże u Drygasa to samo estetyczne wyrafinowanie w filmowaniu „gadających głów”, które nagle staje się czymś więcej: autentycznym spojrzeniem w głąb danego człowieka[17].

Andrzej Werner w eseju dołączonym do wydania filmów Drygasa na DVD konstatuje:

Film dokumentalny jest dziś w niewoli mediów, przede wszystkim - telewizji. A to znaczy na ogół podporządkowanie ich regułom, zwłaszcza pogoni za efektem. Dyskrecja filmów Drygasa sprawia, że znajdują się one na antypodach tego zniewolenia. Dyskrecja i dążenie do prawdy, są one przecież spokrewnione. Dążenie do prawdy nie żywi się łatwym efektem, jeśli prawda bywa efektowna, to tylko dlatego, że jest prawdą[18].

Piotr Lis w recenzji Stanu nieważkości umieszcza zdanie, które można odnieść do całego dorobku twórcy Usłyszcie mój krzyk i Abu Haraz: „Drygas unika i farsy, i politycznego dramatu; interesuje go to, co jest w człowieku w środku"[19].
[16] Ibidem.

[17] M. Oleszczyk, Od konkretu do kosmosu, „Tygo-

dnik Powszechny" 2007, nr 15, s. 23.
[18] A. Werner, Kronikarz lat propagandy, w: Polska Szkoła Dokumentu. Maciej Drygas, op. cit., brak numeracji stron.

[19] P. Lis, op. cit., s. 5. 